\title{
Efficacy of the Use of Different Teaching Approaches in Math
}

\author{
Nilda V. San Miguel ${ }^{\mathrm{a}}$, Elymar A. Pascual ${ }^{\mathrm{b}}$ \\ elymarpascual@rocketmail.com \\ ${ }^{a}$ Department of Education, Lumban District, Laguna, Philippines, 4014 \\ ${ }^{\mathrm{b}}$ Department of Education, Nagcarlan Ditrict, Laguna, Philippines, 4002
}

\begin{abstract}
The main focus of this study is exploring the effective approaches in teaching Mathematics that is being applied in public schools, s.y. 2018-2019. This research was written as connected output to the districtwide School Learning Action Cell (DISLAC) on Math teaching approaches which were recently conducted in Victoria, Laguna, Philippines. Fifty-four math teachers coming from 17 schools in Victoria became the respondents of this study. Qualitative method of doing research was applied. Teachers' responses to the following concerns were gathered, analyzed and interpreted: (1) evaluation of the recently conducted DISLAC, (2) status of the use of different approaches, (3) perception on the effective use of approaches, (4) preference of approach to explore in classroom sessions, (5) factors affecting the choice of approach, (6) difficulties encountered, (7) and perceived benefit to learners. Results showed that the conduct of DISLAC was very highly satisfactory (mean 4.41). Teachers looked at collaborative approach as very highly effective (mean 4.74). Fifty-two percent of the teachers is using collaborative approach, $17 \%$ constructivist, $11 \%$ integrative, $11 \%$ inquiry-based, and $9 \%$ reflective. Reflective approach was chosen to be explored by most of the respondents $(29 \%)$ in future sessions. The difficulties encountered by teachers in using the different approaches are: (1) learners' difficulty in following instructions, (2) lack of focus, (3) lack of willingness and cooperation, (4) teachers' lack of mastery in using different approaches, and (5) lack of time of doing visual aids because of time mismanagement. Teachers deemed the use of various teaching approaches can help the learners to have (1) mastery of competency, (2) increased communication, (3) improved confidence, (4) facility in comprehension, and (5) better academic output. The result obtained from this study can be used as an input for SLACs. Recommendations at the end of the study were given to school/district heads and future researchers.
\end{abstract}

Keywords: approaches; collaborative; constructivism; integrative; inquiry-based; reflective

\section{Introduction/Background}

Different countries promote different approach to be used in Mathematics. One educator commented that Mathematics is the most important core subjects in any level of study because it affects one's decisionmaking, logical and creative thinking. Although Math teachers around the world may not agree on the most appropriate teaching approach to be used, there are important concepts that we can learn and utilize from known proponents of teaching approach. The concepts of Piaget, as an example, who is a proponent of constructivism, still ring out loudly in our present generation as we realize that students learn best when they are able to make meaning out of their learning, when they are able to express how those things they have learned are able to impact their life or give significance to their being. It is surprising to note that Taiwan, a small country and yet passionate in the search of applicable approach in the classroom setting of their country, 
found out in one of their study that, indeed, constructivism is applicable in their country's setting.

The Department of Education country signed a law (R.A. 10533, Sec. 5e) that mandates the use of the different approaches - constructivism, collaborative, integrative, inquiry-based, and reflective. How are these teaching approaches being used in the District of Victoria in Laguna? What are the difficulties that they are encountering in the implementation of these approaches in classroom setting? There are just some of the issues that this paper would explore.

\subsection{Statement of the Problem}

The main concern of this action research is to find out the effective approach in teaching that is being used by Mathematics teachers in Victoria, Laguna.

Specifically, it seeks to answer the following questions:

- What is the status of the seminar/workshop handled about teaching approach in Mathematics which was conducted in Victoria, Laguna?

- What is the status of the use of the different teaching approaches in Mathematics in Victoria, Laguna:

* Collaborative;

* Constructivist;

* Integrative;

* Inquiry-based; and

* Reflective?

- What approach in teaching Mathematics is commonly used in Victoria, Laguna?

- Which among the five approaches the teachers would like to explore in preparing for class sessions?

- What are the teachers' difficulties in the use of the different teaching approaches in Mathematics?

- What are the factors that affect the choice of teachers in the approach that they are going to use inside the classroom?

- Why do they think this would improve the learners' academic performance if used in classroom teachings?

\section{Review of Related Literature}

The distinction between the characteristics of a 'good' teacher, which include both a deep understanding of mathematics and an ability to engage with the learners' interests, and a 'really good' teacher, who looks for opportunities to 'seize the teachable moment' (Benson 2002), is a theme that runs throughout this article.

For example, in some education systems, such as that of the Netherlands, 4 broad statements and objectives are provided at the mega level for both socio-political and educational purposes, but, at the micro level, the details and interpretation of these statements for school purposes and the classroom work scheme are left to the teachers and textbook writers (Thijs \& Van den Akker 2009).

The rationale for the change is that our teachers are deemed not capable of interpreting an objectivesbased curriculum, or of transforming these objectives into instructional units (Dada, et al, 2009).

Dunne (2014) in his study discussed three approaches that inform the teaching of mathematics in the primary school and which may be taken singly or in conjunction into organising the curriculum: the topics approach, the process approach, and the conceptual fields approach.

McAninch (2015) conducted a study on secondary mathematics teachers' questioning. The results found through this qualitative study suggest benefits for practicing teachers to expand the types of questions they use in the classroom, making particular efforts to include those areas that teachers from this study showed to be most lacking: semantic tapestry questions that help students build a coherent mental framework related to a mathematical concept, and framing questions that help frame a problem and structure the 
discussion that follows.

Sofroniou and Poutos (2016) made a study on the effect of group work. The group work sessions were conducted over four weeks whilst studying the topic of integration. Evaluation surveys were collected at the end of the intervention along with an investigation into the examination results from the end of semester examinations. The investigation into the effectiveness of group work showed interesting and encouraging positive outcomes, supported by a combination of qualitative and quantitative analysis.

Ünal (2017) investigated on the teachers' preference of teaching method. While analyzing the data, a categorical descriptive analysis technique was employed in which participants' opinions were divided into categories and sub-categories, and quotations were included to ensure opinions were reflected accurately. Results of these interviews showed that teachers preferred techniques such as "Question and Answer" and "Demonstration," that offered relative ease of use. Techniques such as "Scenario" and "Case Study" had fallen out of favor, as they required greater preparation and use of educational materials.

Chi (2015) investigated on the teaching modes and Taiwanese student learning. The investigation revealed that the constructivist approach seems to be an excellent medium to provide quality education. It is recommended that educators should re-introduce the use of a constructivist approach to teaching Mathematics because of its potential to enhance the quality of Mathematics education, which in turn augments students' competency as future Mathematicians.

Opponents of a constructivist approach to teaching have contended that this approach "should only be used for children with developmental delays". However, Wei and Eisenhart (2011) cautioned such teachers to reconsider their attitudes because a focus on developing mathematical skills void of conceptual understanding may lead to mathematics instruction that is "rigid and often boring".

Teacher questioning, a part of teacher quality related to classroom practice, has received researchers' attention as being a salient difference between teacher-centered and student-centered environments (Almeida $\&$ de Souza, 2010).

Teachers go from being a direct lecturer, or giver of information, to more of a facilitator of student learning through discussion (Hoffman et al, 2012).

Where discourse in a traditional classroom takes on an initiation-response-feedback (IRF) chain that is framed by the teacher and ends with the teacher evaluating the response and providing affirmation or corrective feedback, an adjustment to the last piece of the sequence could open up the discourse to allow students to become "co-constructors of meaning" (Chin, 2006).

Because a teacher says much less in a student-centered classroom, the content of each teacher's utterance is valuable in framing the discussion. In this age of increasing teacher accountability due to NCLB and RTTT requirements (USDOE, 2013), teachers are under pressure to perform well and need to be able to improvise during any teacher-student interaction (Ruiz-Primo \& Furtak, 2007).

Hogan and colleagues (2003) showed that expert teachers presented mathematical content more conceptually and better predicted students' attained comprehension and misconceptions.

\section{Research Design and Methodology}

\subsection{Research Design}

This research operated on a descriptive method of doing research, specifically, the qualitative method. Through this design, questions posted at the beginning of the study were answered though the data collected from survey questions. As Ogula (2005) describes research design a plan, structure and strategy of investigation to obtain answers to research questions and control variance, so this method of doing research was the one appropriate for the present study. Under this method, qualitative data were processed, analyzed, sorted and interpreted. 


\subsection{Data Gathering Procedure}

This flowchart highlights steps undertaken in conducting this action research.

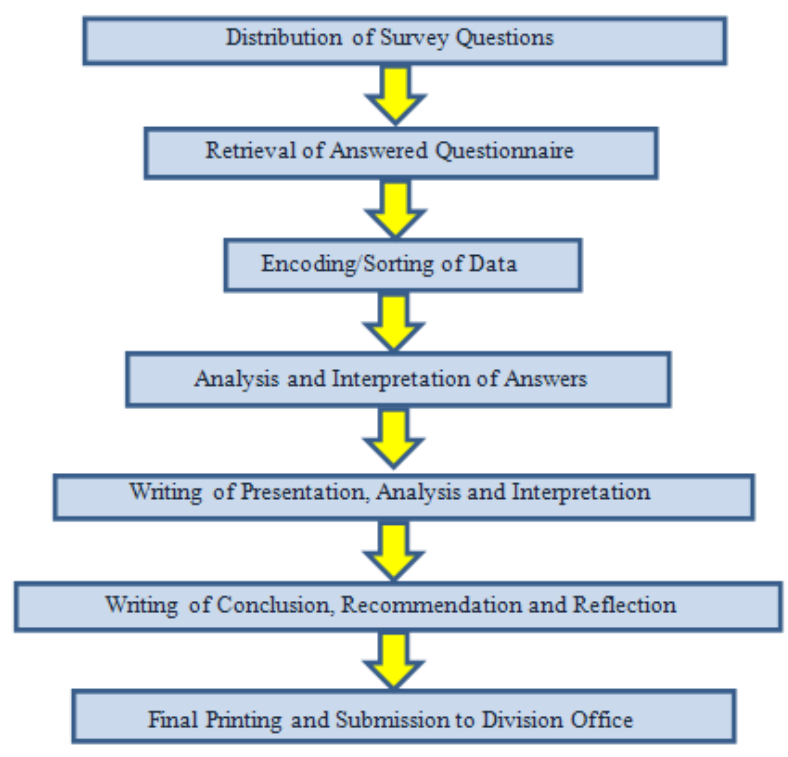

Fig. 1. Flowchart of research procedure

\subsection{Research Respondents}

All Mathematics teachers in the seventeen schools in the district of Victoria will be the subject/respondent for this study. The frequency and total is presented below:

Table 1. Frequency of the respondents per school

\begin{tabular}{|l|c|}
\hline \multicolumn{1}{|c|}{ School } & Number of Math Teachers \\
\hline 1. Pagalangan Elementary School & 4 \\
\hline 2. San Roque National High School & 2 \\
\hline 3. Daniw Elementary School & 4 \\
\hline 4. San Benito Elementary School & 4 \\
\hline 5. San Benito National High School & 2 \\
\hline 6. Masapang Elementary School & 4 \\
\hline 7. Masapang Integrated National High School & 2 \\
\hline 8. Banca Banca Elementary School & 4 \\
\hline 9. Banca Banca Integrated National High School & 2 \\
\hline 10. San Francisco Elementary School & 4 \\
\hline 11. San Francisco Integrated National High School & 2 \\
\hline 12. Gregoria Herradura Elementary School & 4 \\
\hline 13. Nanhaya National High School & 2 \\
\hline 14. Victoria Elementary School & 4 \\
\hline 15. Victoria Senior High School & 2 \\
\hline 16. San Felix Elementary School & 4 \\
\hline
\end{tabular}




\begin{tabular}{|c|c|}
\hline 17. Tomas Daquinsin Elementary School & 4 \\
\hline Total & 54 \\
\hline
\end{tabular}

\subsection{Data Collection}

Answers to every question in the SOP will be gathered through teacher's response in the survey question that will be distributed to them. The detail for every question is presented below:

SOP \#1 - A five-item Likert-scale questionnaire which was the rating that teachers gave in the recently conducted seminar-workshop about teaching approaches. This seminar-workshop was organized and conducted by the researchers of this study last September 18, 2018.

SOP \#2 - A five-item Likert-scale system was utilized to have a status of the implementation of the different teaching approaches which was discussed in the seminar-workshop that the teachers attended.

SOP \#3 - An open-ended question

SOP \#4 - An open-ended question

SOP \#5 - An open-ended question

SOP \#6 - An open-ended question

SOP \#7 - An open-ended question

\subsection{Treatment of Data}

Indicated below was the manner on how the data was analyzed:

SOP \#1 - using mean and standard deviation

SOP \#2 - using mean and standard deviation

SOP \#3 - using frequency and percentage

SOP \#4 - using frequency and percentage

SOP \#5 - sorting and analysis

SOP \#6 - sorting and analysis

SOP \#7 - sorting and analysis

\section{Presentation, Analysis and Interpretation of Data}

4.1. Status of Seminar/Workshop on Teaching Approach in Mathematics

Table 2. Mean level status of seminar/workshop on teaching approach held in Victoria, Laguna

\begin{tabular}{|c|c|c|c|}
\hline Indicators & Mean & SD & Interpretation \\
\hline $\begin{array}{l}\text { 1. The DISLAC was conducted on a convenient time wherein teachers } \\
\text { can freely participate and learn from the discussion. }\end{array}$ & 4.58 & 0.51 & $\begin{array}{l}\text { Very Highly } \\
\text { Satisfactory }\end{array}$ \\
\hline 2. The DISLAC went well and everyone understands the topic discussed. & 4.37 & 0.68 & $\begin{array}{l}\text { Very Highly } \\
\text { Satisfactory }\end{array}$ \\
\hline $\begin{array}{l}\text { 3. The ideas presented in the DISLAC are issues or topic that can help } \\
\text { teachers grow in their teaching approaches inside the classroom. }\end{array}$ & 4.53 & 0.61 & $\begin{array}{l}\text { Very Highly } \\
\text { Satisfactory }\end{array}$ \\
\hline 4. The speaker answered questions politely and clearly. & 4.47 & 0.84 & $\begin{array}{l}\text { Very Highly } \\
\text { Satisfactory }\end{array}$ \\
\hline 5. The venue of the DISLAC was comfortable. & 4.11 & 0.88 & Highly Satisfactory \\
\hline $\begin{array}{l}\text { 6. The DISLAC became an avenue for clearing things with regards to the } \\
\text { topic. }\end{array}$ & 4.26 & 0.87 & $\begin{array}{l}\text { Very Highly } \\
\text { Satisfactory }\end{array}$ \\
\hline $\begin{array}{l}\text { 7. The DISLAC is academic in nature and provides information that is } \\
\text { necessary for educative process. }\end{array}$ & 4.47 & 0.61 & $\begin{array}{l}\text { Very Highly } \\
\text { Satisfactory }\end{array}$ \\
\hline
\end{tabular}




\begin{tabular}{|c|c|c|c|}
\hline $\begin{array}{l}\text { 8. Other attendees of the DISLAC are cooperative and willing to accept } \\
\text { ideas from others. }\end{array}$ & 4.32 & 0.75 & $\begin{array}{l}\text { Very Highly } \\
\text { Satisfactory }\end{array}$ \\
\hline $\begin{array}{l}\text { 9. The speaker has a mastery of the topic and was able to deliver the } \\
\text { information with confidence. }\end{array}$ & 4.53 & 0.51 & $\begin{array}{l}\text { Very Highly } \\
\text { Satisfactory }\end{array}$ \\
\hline $\begin{array}{l}\text { 10. The DISLAC can be shared to other school because the topic is } \\
\text { interesting. }\end{array}$ & 4.47 & 0.61 & $\begin{array}{l}\text { Very Highly } \\
\text { Satisfactory }\end{array}$ \\
\hline Average & 4.41 & 0.69 & $\begin{array}{l}\text { Very Highly } \\
\text { Satisfactory }\end{array}$ \\
\hline
\end{tabular}

Legend:

$\begin{array}{ll}4.21-5.00 & \text { Very Highly Satisfactory } \\ 3.41-4.20 & \text { Highly Satisfactory } \\ 2.61-3.40 & \text { Satisfactory } \\ 1.81-2.60 & \text { Fairly Satisfactory } \\ 1.00-1.80 & \text { Unsatisfactory }\end{array}$

Table 2 shows the rating given by 54 teachers to the District School Action Cell about Math teaching approaches. Nine out of 10 indicators received a very highly satisfactory rating. The item that received a little lower rating (highly satisfactory, 4.11) was with regards to the venue. The venue used was not an enclosed place, making the classes surrounding the venue of the DISLAC disrupted because of the sound system. Nevertheless, the overall rating was very highly satisfactory (4.41) with a standard deviation of 0.69 which means that the teachers' responses are comparable to each other or homogenous.

\subsection{Effective Use of Different Teaching Approaches in Mathematics}

Table 3. Mean level of teachers' perception on the effective use of different teaching approaches in Mathematics in Victoria, Laguna

\begin{tabular}{|c|c|c|c|}
\hline Teaching Approach & Mean & SD & Interpretation \\
\hline Collaborative & 4.74 & 0.45 & $\begin{array}{c}\text { Highly Effectively Used in } \\
\text { Teaching }\end{array}$ \\
\hline Constructivist & 4.00 & 0.58 & Effectively Used in Teaching \\
\hline Integrative & 4.11 & 0.94 & Effectively Used in Teaching \\
\hline Inquiry-based & 4.00 & 0.75 & Effectively Used in Teaching \\
\hline Reflective & 3.79 & 1.08 & Effectively Used in Teaching \\
\hline
\end{tabular}

Legend:

4.21 - 5.00 Highly Effectively Used in Teaching

$3.41-4.20$ Effectively Used in Teaching

2.61 - 3.40 Fairly Effectively Used in Teaching

$1.81-2.60$ Not Effectively Used in Teaching

$1.00-1.80$ Not at all used in teaching

Table 3 shows perception of the 54 Math teachers with regards to the teaching approach that is being effective inside the classroom. As shown above, the most effective was collaborative approach, having a rating which is interpreted as highly effective (mean of 4.74 and sd 0.45 ). Nevertheless, the other approaches got a rating which is interpreted as effective. If collaborative is the most effective, the least effective as seen from the mean (3.79) is reflective approach. Teachers are having varied notion about the effectiveness of reflective approach as implied by $1.09 \mathrm{sd}$ which is greater than 1 . Some may be looking into reflective approach as fairly effective only, while others were viewing it as effective. 


\subsection{Status of Teachers' Use of Different Approaches in Mathematics}

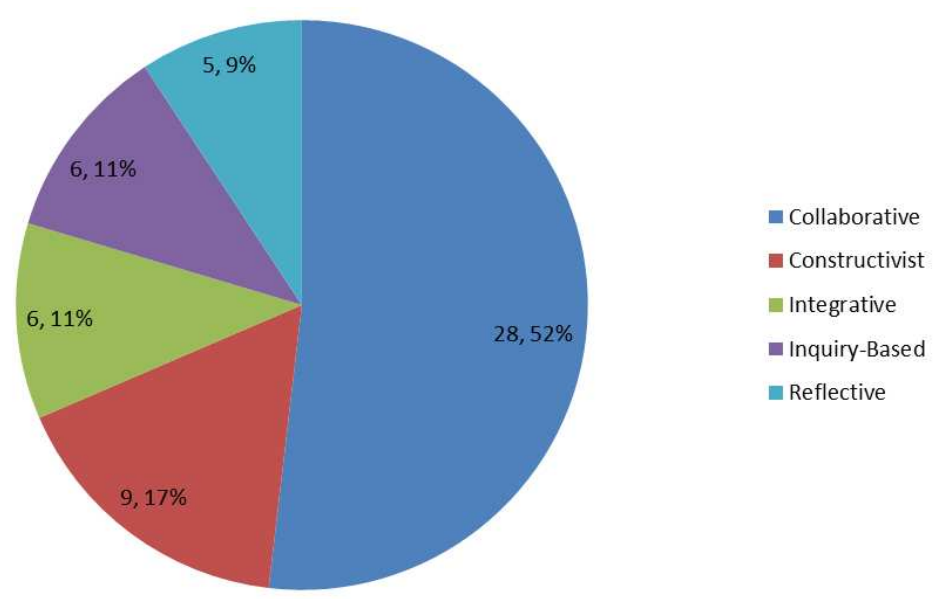

Fig. 2. Frequency and percentage of teachers using different approaches in teaching Math in Victoria, Laguna

The figure above shows the number of teachers who are primarily using one of the approaches of 2C-2I-1R (collaborative, constructivist, integrative, inquiry-based, and reflective). Most of the teachers are using collaborative approach as reflected by twenty-eight teachers or $52 \%$ of the 54 respondents. Constructivist approach was being used by $17 \%$ ( 9 teachers) of the respondents, integrative was $11 \%$ (6 teachers), inquiry based was also $11 \%$ (6 teachers), and reflective was $9 \%$ ( 5 teachers). This did not mean that teachers are only using one approach. This just shows that the approach that teachers have selected was the approach that they frequently use. If collaborative approach was the most used, reflective approach was the least used, or the least to be selected as a way of delivering knowledge in Mathematics.

\subsection{Teachers' Preference of Approach to Explore in Classroom Sessions}

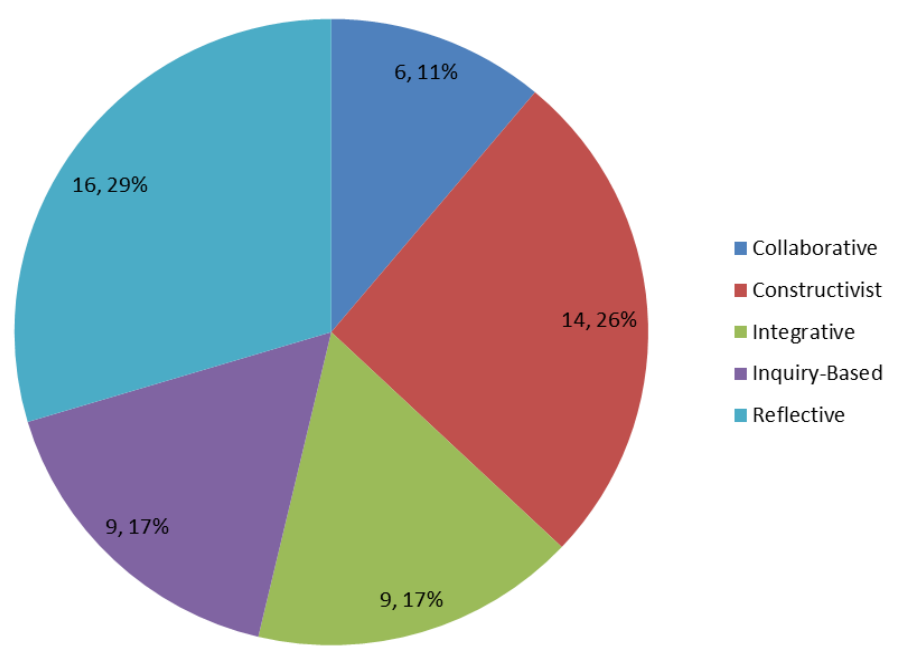

Fig. 3. Choice of approach to explore in next teaching sessions 
The figure in the previous page shows the teaching approach that the 54 teachers chose to explore in the next classroom sessions. Six teachers (11\% of the total respondents) would like to explore the collaborative approach, 14 teachers $(26 \%)$ constructivist approach, 9 teachers $(17 \%)$ integrative, also 9 teachers $(17 \%)$ inquiry-based, while 16 teachers $(29 \%)$ reflective. It can be observed that because reflective approach was the least effective according to them (see Table 3), they would like to explore using it. It might be that they deemed it least effective because they don't have a thorough knowledge on how to use it, that is why they want to explore it.

\subsection{Response to Survey Questions}

This table presents the teachers' selected or representative responses to the questions on difficulties they encountered on the use of different teaching approaches, the factors that influence them or the concept about the approach that leads them in using it, and their view on the benefits of using various approaches in teaching Mathematics.

Table 4. Response to survey questions regarding difficulties encountered, factors affecting choice and benefits of using various approaches

\begin{tabular}{|c|c|}
\hline Questions & Representative/Selected Answers \\
\hline $\begin{array}{l}\text { 1. What are your difficulties in } \\
\text { using the different approaches } \\
\text { in teaching? }\end{array}$ & $\begin{array}{l}\text { * Familiarization about using these approaches } \\
\text { * Sometimes, only few share their ideas so the others were left behind or they just kept their thoughts } \\
\text { only to themselves. } \\
\text { * Learners who have difficulty in following instructions } \\
\text { * Lack of focus during class } \\
\text { * Lack of experience/mastery in utilizing these approaches } \\
\text { * Capacity level of the pupils } \\
\text { * Self-discipline when having group activity } \\
\text { * Time in doing visual aid } \\
\text { * Designing specific task for making learning easier and more transferable to new situations } \\
\text { * Some students are hesitating to raise questions and to voice out their opinions during the discussion } \\
\text { * Teachers have too many roles/work; not enough time to plan } \\
\text { * Learners have different level of abilities, learning and knowledge } \\
\text { * Lack of learners' willingness and cooperation } \\
\text { * Minimizing time to finish every activity in a time allotted } \\
\text { * Pupils' low capability in analysing word problem, having difficult time to figure out what operation } \\
\text { to use }\end{array}$ \\
\hline $\begin{array}{l}\text { 2. With the approach that you } \\
\text { are mostly use, what makes } \\
\text { you at ease in using it? }\end{array}$ & $\begin{array}{l}\text { * Collaborative - ideas and opinions of learners are collected and discussions are going so well since } \\
\text { they participate with ease } \\
\text { - learners learn something as a team. Learning something together makes this approach easy } \\
\text { Mathematical discussion. } \\
\quad \text { - learners enjoy doing activities in this approach } \\
\quad \text { - allows each pupil to cooperate with each other and give their idea or answer questions in a } \\
\text { topic } \quad \text { * Constructivist - learning takes place if the learners experience it first and rather than simply spoon- } \\
\text { feeding them } \\
\text { * Integrative - because the pupils can easily understand the lesson if they have experienced it first-hand } \\
\text { * Integrative - because the learners can easily relate in every situation they encounter } \\
\quad-\text { it relates real-life situation where Mathematical problems could most likely to happen } \\
\text { applied } \quad-\text { process of making connections and experiences so that information and skills can be } \\
\text { * Inquiry-based - learning becomes an active one by posing questions, problems and scenarios. The } \\
\text { process is often assisted by facilitator. }\end{array}$ \\
\hline
\end{tabular}




\begin{tabular}{|c|c|}
\hline $\begin{array}{l}\text { 3. Why do you think that the } \\
\text { use of different approaches } \\
\text { would improve the learners' } \\
\text { academic performance? }\end{array}$ & $\begin{array}{l}* \text { The learner can easily relate to the different situation that they will encounter and apply it in their } \\
\text { academic. } \\
* \text { If these strategies will be mastered and used, different learning will be gained. } \\
\text { * Learners learn best if they can able to reflect, experience and construct their own understanding of } \\
\text { the lesson. } \\
\text { * Since the 2C-2I-1R approaches are composed of } 5 \text { different styles, it can accommodate the different } \\
\text { needs and interest of learners. } \\
\text { * Teaching with different approaches will maximize the learning outcome of the students. } \\
* \text { Because these approaches will improve their skill to think deeper and have them come up with } \\
\text { meaningful context of the lesson on their own. } \\
\text { * Having variety of approaches to utilize would better suit learners in learning. } \\
* \text { Using different approaches, it would require learners less time in grasping knowledge. } \\
* \text { They are given the opportunity to nurture their skills, improve their communication and increase their } \\
\text { confidence. } \\
* \text { As multiple intelligences is with students having different learning styles and ability to cope, the use } \\
\text { of these various approaches can widely help. } \\
* \text { Using these different approaches, competencies can be mastered and applied to real-life situations. } \\
* \text { These enable pupils to evaluate their performance if they will be allowed to engage in different } \\
\text { activities that can be connected to real life. } \\
* \text { So that they can explore the way that the materials or topic is being presented. } \\
* \text { Using these approaches, pupils can construct their own Mathematical problem, and it would mean } \\
\text { that they have knowledge about Mathematics concept. }\end{array}$ \\
\hline
\end{tabular}

The difficulties encountered by teachers in using the different approaches are:

- learners' difficulty in following instructions

- learners' lack of focus during class discussion

- learners' lack of willingness and cooperation.

- teachers' lack of mastery in using different approaches,

- lack of time of doing visual aid because of time mismanagement

Learners' part on the difficulty of applying different approaches is left to the teachers to resolve by using techniques to battle against learners weakness. The more important issue is on the aspect of the teachers. Wei and Eisenhart (2011) cautioned such teachers to reconsider their attitudes because their profession requires that they continually grow in knowledge and mastery, and also a proper way of dividing time between personal and professional matters.

Teachers' choice in selecting specific approach depends on the following:

- The venue being offered by the approach in having the students experience in themselves the skill they need to learn.

- The manner of assembling knowledge within the learners' context, thereby making them interested because the concept came or discovered by them.

- The opportunity for enhancement of skill.

- The allowance for self-evaluation and self-checking of the concepts being taught.

- The avenue for asking questions, or being able to think deep because of the guided questions given by the teachers.

This line-up has a glimpse of congruency with the result of the study made by Ünal (2017). According to his paper, teachers preferred techniques such as "Question and Answer" and "Demonstration," that offered relative ease of use.

In all of the difficulties being encountered by teachers, they still see that the use of varied teaching approaches can help the learner to have:

- mastery of competency

- increased communication

- improved confidence

- facility in comprehension

- better academic output 
Hogan and colleagues (2003) showed that expert teachers explore on different approaches to better predict students' attained comprehension and misconceptions w/c speaks in addition \& support of the result in this study.

\section{Conclusion, Recommendation and Reflection}

This chapter highlights the answer to the inferential question given at the beginning of the study, lines-up recommendations to target persons, and leaves a reflection coming out of the researcher's observation and learning about the present study being undertaken.

\subsection{Conclusion} down here:

To answer the questions posted at the beginning of the study, the following discoveries were laid

1.) The conduct of District School Learning Action Cell was rated as very highly satisfactory.

2.) Collaborative approach was seen to be the most effective way of delivering knowledge in Victoria, Laguna.

3.) This is the reason why Math teachers tend to prefer collaborative approach over the other approaches in teaching.

4.) Teacher would like to explore the least effective approach according to their perception, and that is the reflective approach.

5.) Teachers difficulties in the use of the different approaches in teaching evolves on these five main points: (a) learners' difficulty in following instructions, (b) lack of focus during class discussion, (c) learners' lack of willingness and cooperation, (d) teachers' lack of mastery in using different approaches, (e) lack of time of doing visual aid because of time mismanagement.

6.) The factors affecting the choice of approach by Math teachers are the following: (a) venue for learning-by-doing, (b) assembly of knowledge by learners themselves, (c) opportunity for enhance of skill, (d) allowance for self-evaluation, and (e) avenue for personal growth through questions.

7.) Benefits of using various approaches, and not just clinging on one, are the following: (a) mastery of competency, (b) increased communication, (c) improved confidence, (d) facility in comprehension, and (e) better academic output.

\subsection{Recommendation} given here:

Based from the results obtained in the conduct of this study, the following recommendations are

- Math teachers - Exploring on all five teaching approaches are necessary to deal with learners' different interests, readiness, and skills. Searching out and attending conferences, seminars and workshops to increase awareness and have deep knowledge of the different approaches would greatly help.

- School and District Heads - Using the concepts discovered in this study as input for SLACs and DISLACs would make the gathering interesting for Math teachers, because the issue on pedagogy has never been outdated. It continues to evolve as learners' also changes through the changing times. Therefore, knowledge on best way to deliver knowledge should also be updated every now and then.

- Future researchers - Looking into the approaches that would best fit in different disciplines would be a great exploration for future researches. As best approach depends on the learners and the situation, it would be necessary to explore on the different approach that would best cater the learners in different disciplines. 


\subsection{Reflection}

American farmer president John F. Kennedy once said that "leadership and learning are indispensable to each other". To lead and to be educated will never be separated from one another. It is through leadership that we allow and enable ourselves and those of our followers to take the big leap that will liberate people from ignorance.

Albert the Relentless struggles at what the educational system faces at present. It is evident that through guided leadership, we bridge the gap between challenges and one ultimate goal of eradicating mediocrity. Vision and determination play vital roles in order to achieve success or defy anything standing against the road to victory. Thus, the call to all educators, "Anyone who dares to lead must never stop learning!"

\section{References}

Almeida, P., \& de Souza, F. N. (2010). Questioning profiles in secondary science classrooms. International Journal of Learning and Change, 4(3), 237-251.

Benson, J. (2002). What makes a good mathematics teacher?. UCSMP Newsletter, 30(4).

Chi, H. (2015). Improving the Quality of Mathematics Education: Two Teaching Modes and Taiwanese Student Learning. A thesis Submitted in fulfillment of the requirements for the degree of Master of Philosophy in School of Education. The University of Waikato

Chin, C. (2006). Classroom interaction in science: Teacher questioning and feedback to students' responses. International Journal of Science Education, 28(11), 1315-1346.

Dada, F., Dipholo, T., Hoadley, U., Khembo, E., Muller, S., \& Volmink, J. (2009). Report of the task team for the review of the implementation of the National Curriculum Statement.

Dunne, T. (2014). Approaches to teaching primary level mathematics Caroline Long, Centre for Evaluation and Assessment, University of Pretoria. Email address: Caroline.Long@up.ac.za.Tim Dunne, University of Cape Town. South African Journal of Childhood Education | 2014 4(2): 134-153 | ISSN: 2223-7674 |C UJ

Hoffman, N., Steinberg, A., \& Wolfe, R. E. (2012). Teaching and learning in the era of the common core (pp. 1-68). Students at the Center: Boston: Jobs for the Future.

Hogan, T., Rabinowitz, M., \& Craven III, J. A. (2003). Representation in teaching: Inferences from research of expert and novice teachers. Educational Psychologist, 38(4), 235-247.

McAninch, M. J. (2015). A qualitative study of secondary mathematics teachers' questioning, responses, and perceived influences. University of Iowa.

Ogula, P.A. (2005). Research Methods; Nairobi: CUEA Publications.

Ruiz-Primo, M. A., \& Furtak, E. M. (2007). Exploring teachers' informal formative assessment practices and students' understanding in the context of scientific inquiry. Journal of Research in Science Teaching, 44(1), 57-84

Sofreniou, A. and Poutos, K. (2016). Investigating the Effectiveness of GroupWork in Mathematics. School of Computing and Engineering, University of West London, St. Mary's Road, London W5 5RF, UK

Thijs, A \& Van den Akker, J. (2009). Curriculum in development. Enschede: Netherlands Institute for Curriculum Development (SLO).

Ünal, M. (2017). Preferences of Teaching Methods and Techniques in Mathematics with Reasons. Faculty of Education, Ahi Evran University, Kirsehir, Turkey

Wei, M., \& Eisenhart, C. (2011). Why do Taiwanese children excel at math? Kappan, 95(1), 74-76. 